\begin{tabular}{lcl}
\hline \multicolumn{1}{c}{ A N N A L E S } \\
UNIVERSitATIS & MARIAE CURIE-SKŁODOWSKA \\
LUBLIN - POLONIA & \\
VOL. XXII, 2 & SECTIOK & 2015 \\
\hline
\end{tabular}

Wydział Politologii Uniwersytetu Marii Curie-Skłodowskiej w Lublinie

\author{
KRYSTYNA TREMBICKA
}

\title{
Walczyć z wrogiem - o przemocy fizycznej jako sposobie realizacji komunistycznej myśli politycznej w Polsce Ludowej
}

To Fight with the Enemy - Physical Violence as a Way to Implement the Communist Political Thought in the People's Poland

\begin{abstract}
ABSTRAKT
Przedmiotem artykułu jest przemoc fizyczna jako sposób realizacji komunistycznej myśli politycznej w Polsce Ludowej w latach 1944-1989. Badaniu poddano kategorię wroga. W totalitarnym systemie politycznym istniało sprzężenie zwrotne między rzeczywistością rewolucyjną a wrogiem: z jednej strony, rzeczywistość rewolucyjna nie mogła się obejść bez wroga, który był stały, zmieniał się tylko jego obraz, $z$ drugiej natomiast, istnienie wroga sankcjonowało stosowanie nadzwyczajnych środków. Droga realizacji komunistycznej myśli politycznej uwzględniała pozaprawne sposoby działania. Nieuniknionym elementem rewolucji była przemoc. Przemoc była sposobem realizacji celu tak na etapie walki o władzę, jak i o jej utrzymanie. W Polsce Ludowej sposoby walki z wrogiem były elastyczne, uzależnione od celów i potrzeb: od bezpośrednich represji fizycznych aż po stosunkowo łagodne szykany. Skala represji fizycznych była pochodną ewolucji systemu politycznego Polski Ludowej.
\end{abstract}

Słowa kluczowe: wróg, Polska Ludowa, Polska Zjednoczona Partia Robotnicza, przemoc fizyczna

\section{WSTĘP}

Kategoria wroga, obecna w dokumentach programowych Polskiej Partii Robotniczej i Polskiej Zjednoczonej Partii Robotniczej - partii rządzących Polską Ludową - znalazła odzwierciedlenie w systemie politycznym Polski Ludowej. Jego częścią było sprzężenie zwrotne między rzeczywistością rewolucyjną a wrogiem: z jednej strony, rzeczywistość rewolucyjna nie mogła się obejść bez wroga, który był stały, zmieniał się tylko jego obraz, z drugiej natomiast, istnienie wroga sankcjonowało 
stosowanie nadzwyczajnych środków. Myśl tę dobrze wyraził Jakub Berman, członek władz partyjnych do 1956 r., który uważał, że możliwość realizacji własnej wizji ustrojowej usprawiedliwiała różne nieprawości [Torańska 1989: 90, 157]. Droga realizacji komunistycznej myśli politycznej uwzględniała pozaprawne sposoby działania. Nieuniknionym elementem rewolucji była przemoc. Była ona sposobem realizacji celu tak na etapie walki o władzę, jak i o jej utrzymanie ${ }^{1}$.

Należy stwierdzić, że w Polsce Ludowej sposoby walki z wrogiem były elastyczne, uzależnione od celów i potrzeb: od bezpośrednich represji fizycznych charakterystycznych przede wszystkim dla dwóch pierwszych okresów Polski Ludowej, po dyskryminację materialną, dyskredytację, infiltrację, wymuszanie emigracji, aż po stosunkowo łagodne szykany w postaci odmowy wydania paszportu, aresztu 48-godzinnego, rewizji, zablokowania możliwości awansu, blokady dostępu na studia. Stałym elementem działania była cenzura prewencyjna uniemożliwiająca upowszechnianie wartości alternatywnych wobec komunistycznych i przedstawianie racji opozycji.

Skala represji fizycznych była pochodną ewolucji systemu politycznego Polski Ludowej, w której największe nasilenie represji fizycznych przypadło na dwa pierwsze okresy jej istnienia - lata komunizacji (1944-1947) oraz sowietyzacji (1948-1955).

\section{ZAKRES I ZASIĘG PRZEMOCY FIZYCZNEJ W LATACH 1944-1956}

W latach 1944-1947 terror polityczny był skierowany w stronę różnych podmiotów: grup i organizacji antykomunistycznych, narodowych, ludowych, socjalistycznych, piłsudczykowskich. W następnym okresie terror fizyczny dotknął różnych grup społecznych i zawodowych, w tym także elitę władzy. Sowietyzacja Polski przebiegała podobnie jak w innych państwach radzieckiej strefy wpływów, choć niewątpliwie można znaleźć wiele odrębności.

Przemoc fizyczną wobec różnych osób i grup, w postaci skrytobójstwa czy donosów do Niemców, stosowali komuniści jeszcze w okresie wojny. Pomagały w tym oddziały zbrojne stworzone do walki z Niemcami. Wrogiem była polska klasa polityczna [Gontarczyk 2003: 107, 318 i n.]. Armia Czerwona skutecznie pomagała PPR przez aresztowania, wywiezienie do obozów w ZSRR, procesy. W likwidacji podziemia brały udział oddziały NKWD (Narodnyj Komissariat Wnutriennich Dieł/ Ludowy Komisariat Spraw Wewnętrznych) i „Smiersz” (sowieckiego kontrwywiadu wojskowego) [Chmielarz 1998: 73-81]. Jednym z przykładów takiego działania była akcja w Milanówku w 1945 r. zakończona aresztowaniem przywódców Polskiego Państwa Podziemnego i wywiezieniem ich do ZSRR.

\footnotetext{
1 Potrzebę i uzasadnienie stosowania przemocy w komunistycznej myśli politycznej badała Katarzyna Trembicka [Trembicka 2013: 217 i n.].
} 
W latach 1944-1947 represje objęły w pierwszym rzędzie niemieckie i ukraińskie organizacje zbrojne, organizacje niepodległościowe, realnych wrogów nowej władzy. Terror miał charakter masowy. Represje fizyczne przez osadzenie w obozach spotkały grupy narodowe: osoby narodowości niemieckiej, posiadaczy niemieckiej listy narodowościowej (volkslisty), Ślązaków, których uznano za Niemców, Ukraińców oraz współpracujących z ukraińskimi organizacjami nacjonalistycznymi [Dubiański 2004: 18; Woźniczka 2007: 87, 111].

Jeżeli przyjąć za pewne, że władze wyolbrzymiały zagrożenie ze strony ludności niemieckiej, to należy zarazem podkreślić, iż przesiedlenia i lokowanie Niemców w obozach paraliżowały działalność nazistowskich organizacji (np. Werwolfu) oraz stabilizowały państwo. W obu wypadkach decydowały względy bezpieczeństwa, które miały usprawiedliwiać różne posunięcia wobec Niemców. Represjonowanych osadzano w obozach pracy w Mysłowicach, Jaworznie, Sikawie, Potulicach, skąd kierowano ich do pracy w kopalniach lub w przemyśle. U progu Polski Ludowej realny problem stanowili banderowcy, którzy prowadzili czystkę etniczną w południowo-wschodniej części kraju. Przeciwko Ukraińskiej Powstańczej Armii, terroryzującej ludność polską w województwie rzeszowskim i lubelskim, skierowano regularne wojsko, a walka trwała prawie przez trzy lata. Akcję wojskową, w porozumieniu ze Związkiem Socjalistycznych Republik Radzieckich i Czechosłowacją, uzupełniono o masowe przesiedlenia ludności. Akcja „Wisła” służyła przesiedleniu ok. 140 tys. Ukraińców - obywateli polskich, ze wschodniej i południowej części Polski na ziemie północne i zachodnie i ich rozproszeniu. Bandytów z UPA oraz osoby podejrzane o współpracę z nimi umieszczono w obozie w Jaworznie.

Uznanie mniejszości niemieckiej i ukraińskiej za wroga realnego przyniosło skutki niekoniecznie negatywne. Po II wojnie światowej komunistom udało się zmniejszyć zagrożenie ze względu na wysiedlenia i przemieszczenia ludności. Leszek Olejnik, znawca problematyki, zauważył, że polityka narodowościowa była tą ważną sferą, w której działania władz oraz opinia społeczeństwa były tożsame [Olejnik 2003: 600].

W latach 1948-1956 cechą terroru w wydaniu stalinowskim była powszechność. Represjami mógł być objęty każdy. Celem terroru było zastraszenie społeczeństwa. Na początku stycznia 1953 r. w kartotece ewidencjonującej kategorię podejrzanych znajdowało się aż 5,2 miliona ludzi. Oprócz działalności służb specjalnych wymierzonej w różne grupy społeczne, zawodowe i środowiska polityczne zastraszeniu społeczeństwa jako całości służyły akcje policyjne o charakterze prewencyjnym, które owocowały w jednym momencie aresztowaniami tysięcy osób [Paczkowski 1999: 357]. W ciągu przeszło dziesięciu lat życie straciło ponad 50 tys. osób, spośród nich w wyniku wyroków stracono 2800 osób [Madej, Żaryn, Żurek 2003: XXIV-XXVI]. Irena Rzepińska podała, że w latach 1949-1958 skazano 7644 osób [Rzepińska 1997: 50].

Liczba represjonowanych i skazanych jest trudna do ustalenia. $\mathrm{Z}$ zestawienia dokonanego przez Piotra Majera wynika, że w latach 1944-1956 łączna liczba aresz- 
towanych wyniosła 243 066. Najwięcej osób represjonowano w województwach: lubelskim, rzeszowskim, warszawskim, białostockim, krakowskim oraz kieleckim, bo po przeszło 20 tys. osób. Spośród 17 rodzajów czynów uznanych za przestępstwa najczęściej aresztowani byli skazani za członkostwo w nielegalnej organizacji, nielegalne posiadanie broni, przestępstwa okupacyjne, współpracę z członkami nielegalnych organizacji [Majer 2000: 477]. Dane potwierdzają, że w pierwszym rzędzie represjom podlegali uczestnicy podziemia niepodległościowego i wszyscy, którzy udzielali im jakiegokolwiek wsparcia.

W lutym $1946 \mathrm{r}$. w więzieniach przebywało prawie 121 tys. osób, w tym podległych Ministerstwu Bezpieczeństwa Publicznego prawie 62 tys. Po amnestii w 1947 r. na krótko nastąpił spadek uwięzionych - do 90 tys. W 1950 r. liczba uwięzionych wynosiła prawie 99 tys., w 1951 r. - około 75 tys., 1 października 1952 r. w więzieniach przebywało około 50 tys. ludzi [Dominiczak 1997: 56, 70; Dudek, Paczkowski 2000: 14]. W literaturze przedmiotu istnieją w tej sprawie różne dane ${ }^{2}$. Dane liczbowe, jakimi dysponują badacze, mogą być jedynie szacunkowe. W latach 1947-1949 rocznie aresztowano 30-35 tys. osób; w kolejnych trzech latach liczba aresztowanych osób wzrosła.

Do represji MBP należy dodać działalność Komisji Specjalnej do Walki z Nadużyciami i Szkodnictwem Gospodarczym, która zastosowała wobec prawie 84,2 tys. osób kary pobytu w obozach pracy [Jarosz, Wolsza 1993: 7-36]. Apogeum terroru przypadło na rok 1952. Liczba aresztowanych była zbliżona do skali z lat 1945-1947. W 1952 r. według Andrzeja Paczkowskiego aresztowano ok. 21,3 tys. osób (według Henryka Dominiczaka 19,6 tys.). W rok później represjonowanych było już o połowę mniej, bo 8,7 tys., a w kolejnym roku jeszcze mniej [Majchrzak, Paczkowski 2004: 10-11, 18]. Liczba więźniów antypaństwowych wyniosła odpowiednio: w 1951 r. - 34 042; w 1952 r. - 49 500; w 1953 r. - 30 500; w 1954 r. - 20 429; w 1955 r. - 14849 [Paczkowski 1999: 357]. Z represjami spotkali się słuchacze zachodnich radiostacji. Za słuchanie wrogich rozgłośni do $1956 \mathrm{r}$. sądy skazały 4500 osób [Machcewicz 2007: 86].

Represje dotknęły elitę władzy. Walce z wrogiem ulokowanym w aparacie władzy służyły specjalnie wydzielone jednostki operacyjne MBP: najpierw grupa zwana „aparatem Romkowskiego”, dalej Biuro Specjalne, a następnie Departament X i jego odpowiedniki w województwach, podległe Komisji BP do spraw Bezpieczeństwa Publicznego. Pracą Departamentu sterował „triumwirat”: Bolesław Bierut, Jakub Berman, Hilary Minc [Werblan 1991: 48].

Początkiem represji wobec członka PZPR było usunięcie z partii. W dobie stalinowskiej dalszym ciągiem restrykcji mogło być aresztowanie i wyrok. Aresztowanie Władysława Gomułki 2 sierpnia 1951 r. było wstępem do przygotowania oskarżenia i skazania, tak jak to się stało w innych państwach komunistycznych. W arsenale

2 Tadeusz Wolsza podał, że w 1949 r. w więzieniach było 106 tys., w rok później 98 tys., w 1951 prawie 75 tys., w 1952 - 102 tys. [Wolsza 2001: 239]. 
zarzutów o charakterze ideologicznym znalazło się oskarżenie o odchylenie prawicowo-nacjonalistyczne, pierwszą po wojnie herezję w partii komunistycznej, następnie w latach 1948-1949 o titoizm, a w 1952 r. o kosmopolityzm. W partii komunistycznej kosmopolityzm odnosił się do komunistów pochodzenia żydowskiego i był de facto ukrytym antysemityzmem. Zarzuty o herezję zostały wzmocnione oskarżeniami o współpracę ze służbami specjalnymi (w Polsce z sanacyjnym kontrwywiadem), z gestapo w okresie wojny, a po wojnie o szpiegostwo na rzecz państw kapitalistycznych. Plenum listopadowe w 1949 r. przyniosło Gomułce zarzut zdrady. Śledczy chcieli udowodnić mu szpiegostwo i współpracę z obcym wywiadem.

Ofiary po stronie władzy popadły w tryby potężnej machiny, jaką była policja polityczna. W Polsce aresztowania objęły około 750 osób. Spośród ludzi ulokowanych wysoko w aparacie władzy aresztowano wojskowych i funkcjonariuszy partyjnych. Pierwsze czystki w Ludowym Wojsku Polskim nastąpiły w latach 1952-1953 i dotknęły wysokich rangą oficerów: Mariana Spychalskiego, Michała Żymierskiego, Józefa Kuropieskę, Jerzego Kirchmayera, Stanisława Tatara, Stanisława Nowickiego, Stefana Mossora. W latach 1951-1954 aresztowano i skazano 83 oficerów. W dniach 31 lipca - 13 sierpnia 1951 r. toczył się przed Najwyższym Sądem Wojskowym proces generałów i wyższych oficerów LWP, którzy zostali oskarżeni o przygotowywanie zamachu stanu. Aresztowani oficerowie byli traktowani jak wrogowie narodu, faszyści i „lokaje” imperializmu [Pawlikowski 2004: 50-51; Poksiński 1992 (rozdział II); Ważniewski 1991: 44-45]. Spośród prominentnych funkcjonariuszy partyjnych represje objęły Władysława Gomułkę, Zenona Kliszkę, Ignacego Logę-Sowińskiego, Władysława Bieńkowskiego, Włodzimierza Lechowicza, Alfreda Jaroszewicza [Spałek 2007: 91 i n.; Garlicki 1993: 49]. Dopiero zmiana władzy na Kremlu i wycofanie przez Nikitę Chruszczowa zarzutu o agenturalności Josipa Broz Tito wpłynęły na zmianę stosunku do Gomułki, część zarzutów okazała się nieprzydatna.

Osłabienie terroru można tłumaczyć trzema okolicznościami, które miały wpływ na ochłodzenie entuzjazmu aparatu bezpieczeństwa w ściganiu wrogów Polski Ludowej. Na skalę prześladowań miały wpływ wydarzenia w ZSRR i w innych państwach komunistycznych: 1) śmierć Stalina, aresztowanie i stracenie wysokich rangą funkcjonariuszy aparatu bezpieczeństwa w ZSRR, m.in. Ławrientija Berii, odpowiedzialnego za aparat represji, 2) wystąpienia robotnicze w NRD i w Czechosłowacji, 3) ucieczka Józefa Światły, rangą wysokiego funkcjonariusza resortu bezpieczeństwa. System powszechnych represji nie został wyeliminowany, ale zmniejszyła się skala aresztowań. Można sądzić, że część elity władzy zaczęła się obawiać o bezpieczeństwo osobiste.

Zapoczątkowany w ZSRR proces odwilży nie zapobiegły zbrodniom. Postanowienie o wykonaniu kary śmierci na 19 oficerach LWP podjęto już po śmierci Stalina, podobnie jak o aresztowaniu biskupów i prymasa. Interesujący może być fakt, że w przeprowadzonych procesach główni oskarżeni, wcześniej oficerowie AK, bądź Polskich Sił Zbrojnych na Zachodzie zachowali życie, bo otrzymali wyroki dożywotnie. Wyroki śmierci zapadły w procesach pobocznych. Proces wojskowych, 
w którym głównymi winnymi ostatecznie okazali się oficerowie związani z partią komunistyczną, a nie realni wrogowie, antykomuniści, był przykładem „obiektywnej zdrady"3. Ta zaś musiała skutkować najwyższą karą.

Walka o Polskę świecką, zadanie „zniszczenia agentury watykańskiej”, która kierowała walką przeciwko Polsce Ludowej w wydaniu komunistycznym skutkowała różnymi działaniami wymierzonymi w Kościół katolicki, jako instytucję i duchownych. Represje fizyczne dotknęły duchowieństwo w pierwszej połowie lat 50. XX w. Objęly kilku biskupów, kilkuset księży, siostry i braci zakonnych. Do 1956 r. aresztowano około 1000 księży [Żaryn 2005: 27].

PZPR akceptowała przemoc w stosunku do chłopów [Bierut 1951: 84]. W efekcie kolektywizacji represje dotknęły także kilkaset tysięcy chłopów. W latach 1949-1956 aresztowano i przekazano sądom prawie 88 tys. osób. Największe represje wystąpiły do 1953 r. [Krupa 2006: 193]. Przestrogi, aby je ograniczyć, pojawiły się wtedy, gdy pogłębiły się trudności żywnościowe [Minc 1951: 23-24]. Oprócz aresztowań stosowano inne sankcje: zajmowanie i licytacja dobytku, palenie chłopskiego mienia, niszczenie żywności, kradzieże. Formą nacisku była aktywność Lotnych Brygad Kawalerii, czyli grup młodych ludzi, niekiedy z kryminalną przeszłością, powołanych spośród aktywu Związku Młodzieży Polskiej przez lokalnych sekretarzy. Grupy te dopuszczały się ekscesów: demolowanie mieszkań, niszczenie mienia, urządzanie libacji, bicie i poniżanie chłopów [Gryciuk 2003: 156].

$\mathrm{W}$ drugiej połowie lat $40 . \mathrm{XX}$ w. represje fizyczne spotkały inteligencję związaną z podziemiem antykomunistycznym. Natomiast większości uczonych z powodu głoszonych poglądów groziły przede wszystkim różne utrudnienia, rzadko utrata etatu. Realną karą było odsunięcie od zajęć dydaktycznych ale już niekoniecznie od pracy naukowo-badawczej. ${ }^{4}$ Niemniej jednak można stwierdzić, że wysoko wykwalifikowana inteligencja stała się wielką przegraną transformacji ustrojowej. Wykonujący wolne zawody ludzie zarabiali co prawda więcej niż inne grupy społeczne, ale mniej niż przed wojną czy w państwach demokratycznych. Inteligencja w stosunku do sytuacji sprzed wojny utraciła wiele: wysokie zarobki, pozycję społeczną, prestiż. W inteligencję godziła rewolucja kulturalna, która skutkowała rozbiciem ,warstw społecznych będących nośnikiem starych, odrzucanych wartości” [Paczkowski 1994: 68-69].

\section{ZAKRES I ZASIĘG PRZEMOCY FIZYCZNEJ W LATACH 1956-1989}

Po 1956 r. rządzący odrzucili terror polityczny i nagminne łamanie prawa. Przemoc fizyczną stosowano w obliczu buntów społecznych wobec strajkujących robotników oraz aktywnych przeciwników systemu komunistycznego.

\footnotetext{
3 O typologii komunistycznych wrogów [zob. Trembicka 2013: s. 24 i n.].

4 Według Henryka Słabka dotyczyło to nie więcej niż 40 uczonych [Słabek 1996: 261; 1995: 113].
} 
W latach 1956-1989 polityka władz wykazała się znaczną elastycznością: od aresztowań i prób likwidacji grup opozycyjnych, przez kontrolę i tolerowanie tajnej działalności, aż po zamiar wmontowania części opozycji politycznej w system polityczny. Należy stwierdzić, że wśród działań wymierzonych w różne grupy opozycyjne charakterystyczne było „nękanie” uczestników grup opozycyjnych, tworzenie politycznej alternatywy dla grupy opozycyjnej w tym samym środowisku, kompromitowanie członków opozycji, pobicia, tworzenie spośród aktywistów młodzieżowych bojówek i dezorganizowanie wkładów organizowanych przez Towarzystwo Kursów Naukowych, paraliżowanie kanałów przepływu środków finansowych i urządzeń technicznych, konfiskowanie książek, papieru do pisania, urządzeń poligraficznych oraz wydrukowanych materiałów, kary dla właścicieli mieszkań, w których odbywały się niezgodne z prawem spotkania, rewizje. Po 1956 r. zdarzyły się zbrodnie, ale były one incydentalne.

System poststalinowski w stosunku do stalinowskiego uniknął rozmyślnego i systematycznego unicestwiania członków aparatu, zwyciężonych w walkach frakcyjnych, co dało poczucie bezpieczeństwa funkcjonariuszom partyjnym oraz nomenklaturze [Morin 1990: 110]. Za Gomułki odosobnionym przypadkiem był los Stanisława Wawrzeckiego, jednego z dyrektorów centrali handlowej, skazanego na śmierć za nadużycia finansowe i spekulację. Wymierzona kara była w sposób oczywisty nieadekwatna do winy. Nagłośnione aresztowanie i proces miały wówczas pokazać determinację obozu władzy w walce z nadużyciami gospodarczymi. Wawrzecki stał się kozłem ofiarnym w okresie kryzysu w zaopatrzeniu miast. W ówczesnej sytuacji wykreowanie wroga w postaci spekulantów pozwoliło rządzącym przynajmniej na krótki czas odwrócić uwagę opinii publicznej od faktycznych powodów kiepskiego zaopatrzenia sklepów, zwłaszcza niewystarczającej ilości mięsa i wędlin.

1956 rok miał wpływ na styl sprawowania władzy i ograniczenie represyjności systemu. Stwierdzić trzeba, że mimo amnestii, liczni bohaterowie walki o niepodległość wyszli na wolność długo po 1956 r. W roku tym nie uwolniono osób skazanych w latach 1952-1953 na karę śmierci, którym zmieniono wyrok na długoletnie więzienie [Madej, Żaryn, Żurek 2003: XIX]. Nawet po wyjściu na wolność pozostali w kręgu zainteresowania SB, jako wrogowie potencjalni.

$\mathrm{Z}$ represjami spotkali się np. z piłsudczycy, którzy podjęli próbę odtworzenia organizacji w postaci Stronnictwa Niezawisłości Narodowej. Aresztowani aktywiści byli sądzeni z paragrafów działalności „,na szkodę narodu polskiego” odnoszącą się do lat 30. XX wieku oraz współpracę z ,reakcyjnym podziemiem” i szpiegostwo [Woźniczka 1996: 111, 119].

W stosunku do duchowieństwa w miejsce terroru fizycznego zastosowano przede wszystkim bodźce ekonomiczne. W dobie Władysława Gomułki, Edwarda Gierka i Wojciecha Jaruzelskiego w stosunku do duchownych stosowano politykę ,kija i marchewki”, czyli w zależności od postawy względem państwa karę bądź nagrodę. Wzmożona egzekucja podatków miała być tak realizowana, żeby godzić w instytucję, a nie w księży. Marchewką miało być łagodne ściąganie podatków oraz sprawozdań 
z działalności punktów katechetycznych od posłusznych księży, opłacanie katechetów, zapewnienie duchownym emerytur, pomocy lekarskiej. Formą szykany było wykorzystanie prawa i pobór do wojska. Zauważono, że pobór alumnów do wojska przynosił sukces, gdyż duży ich procent nie wracał do seminariów. Jeżeli chodzi o skuteczność stosowanej polityki, zwłaszcza „wzmocnień” materialnych, to Kościół nie uległ pokusie. W 1971 r. zauważono jednocześnie, że szkodliwe było nadmierne stosowanie środków administracyjnych ${ }^{5}$.

W latach 70. i 80. XX w. unikano bezpośredniego starcia z Kościołem na rzecz prewencji i zapobiegania, aby zmniejszyć liczbę kandydatów do seminariów, przeciwstawić się nieuzgodnionym budowom kościołów. Podjęto próbę eliminacji niektórych hierarchów przez usunięcie z zajmowanego stanowiska.

System represji selektywnych, charakterystyczny dla lat 1956-1981, skutkowal działaniami przeciwko wybranym środowiskom społecznym i politycznym w chwilach podejmowania przez nie ważnych inicjatyw przeciwko rządzącym. W ramach „miękkiej” represji czasami zaostrzano politykę, a tym samym wzmagano prześladowania. Niemniej jednak w całym okresie liczba więźniów politycznych jednorazowo nie przekraczała kilkudziesięciu osób.

Aresztowania i wyroki skazujące objęły uczestników zorganizowanego działania przeciwko państwu. Przykładem mogły być represje, które dotknęły członków organizacji „Ruch”. Założona na przełomie lat 1965 i 1966 w Lublinie i Łodzi organizacja niepodległościowa, jednoznacznie antykomunistyczna, zaznaczyła swoje istnienie tak spektakularną inicjatywą, jak próba podpalenia Muzeum Lenina w Poroninie w setną rocznicę urodzin przywódcy bolszewików, co miało się stać 21 czerwca 1970 r. Służba Bezpieczeństwa, aresztując prawie 100 osób, doprowadziła do rozbicia organizacji. Wyroki skazujące dotknęły co czwartą aresztowaną osobę i były wysokie (do 7 lat; Ryszard Kowalczyk otrzymał wyrok 25 lat). W 1965 r. aresztowano i skazano Jacka Kuronia i Karola Modzelewskiego, dysydentów partyjnych, autorów opublikowanego rok wcześniej Listu do partii. Państwo skazało na więzienie młodych ludzi przemycających do Polski emigracyjną literaturę (proces „taterników”).

W 1968 r. użyto przemocy przeciwko wiecującym studentom. Policja oraz członkowie Ochotniczej Rezerwy Milicji Obywatelskiej pobili demonstrantów, aktywnych zaś uczestników demonstracji relegowano z uczelni. Studenci nie mogli podróżować bez przepustek do innych miast, byli inwigilowani. Zatrzymano 2,7 tysięcy osób, około tysiąc było sądzonych, kilkadziesiąt skazano. W 1968 r. grupą najbardziej poszkodowaną byli studenci pochodzenia żydowskiego. Usunięto z uczelni prawie 1500 studentów, a setki skierowano na szkolenie wojskowe [Paczkowski 1995: 336; Stola 2000: 88].

Przywódcy marcowego buntu zostali szybko zwolnieni z aresztów, co wyzwoliło konstatację, że sterujący natężeniem represji starali się, z jednej strony, niejako „przesłać” informację, iż działalność opozycyjna nie będzie tolerowana, a jedno-

${ }_{5}$ Protokót z posiedzenia Zespołu KC ds. Polityki Wyznaniowej w dniu 19 listopada 1971 r., [w:] Tajne dokumenty Państwo-Kościół 1960-1980, Londyn 1996, s. 111, 113, 134, 381. 
cześnie, z drugiej strony, sygnalizować, że władze były skłonne odstąpić od części kary [Kamiński 2003: 12 i n.]. W 1974 r. w wyniku amnestii więzienie opuścili członkowie „Ruchu”. Nie stosowano represji wobec osób, które podpisywały listy protestacyjne, ani nie blokowano powstania nowych struktur: Ruch Obrony Praw Człowieka i Obywatela, Studenckie Komitety „Solidarności”, Towarzystwo Kursów Naukowych, Wolne Związki Zawodowe, Nurt Niepodległościowy.

Względnie liberalna w stosunku do opozycji polityka w dobie gierkowskiej była następstwem co najmniej trzech okoliczności. Pierwszą była przyjęta taktyka, według której po likwidacji zagrożenia wewnątrz partii w postaci rewizjonistów, po pacyfikacji buntu studenckiego i przede wszystkim strajków robotniczych władze nie chciały przez zaostrzenie sytuacji doprowadzić do powtórzenia Marca '68. Opozycja była traktowana jako swoisty „wentyl bezpieczeństwa”, jej istnienie pozwoliło na kanalizowanie niezadowolenia społecznego, zwłaszcza w kręgach inteligenckich. Drugą była słabość opozycji. Rządzący byli przekonani o tym, że opozycja nie stanowiła problemu. Liczebność wszystkich grup opozycyjnych do lata 1980 r. wynosiła niespełna 2-2,5 tys. osób [Kamiński, Piotrowski 2002: 34, 43]. O słabości opozycji zapewniała policja. Likwidacja grup opozycyjnych była nieopłacalna. W miejsce likwidowanych grup mogły powstać inne. Opłacalne było kontrolowanie opozycji. Władze uznały, że opozycja policzona i kontrolowana nie była groźna. Trzecią okolicznością mającą wpływ na taktykę wobec opozycji było détente w stosunkach między Wschodem a Zachodem. Realizacja wizji „drugiej Polski” wymagała wsparcia kredytowego. Władzom zależało na pozytywnym wizerunku. Problem stanowiła pętla zadłużeniowa i potrzeba uzyskania kolejnych kredytów. Powstrzymanie się przed procesami przeciwników ideowych i uwięzieniem miało być przejawem „siły, a nie słabości” rządzących [Gierek 2002: 209]. W dobie gierkowskiej władze miały wiedzę, że trudno byłoby utrzymać specjalne stosunki z państwami zachodnimi, a zwłaszcza pozyskać kredyty, gdyby w ich odczuciu Polska była państwem represyjnym. Gierkowi zależało, aby Polska była postrzegana jako państwo bez więźniów politycznych [Rolicki 1990: 141]. Obawiano się konsekwencji podpisania dokumentów Konferencji Bezpieczeństwa i Współpracy w Europie, zwłaszcza w części dotyczącej praw człowieka (trzeci koszyk).

W latach 70. i 80. XX w. Ministerstwo Spraw Wewnętrznych było gotowe stosować różne warianty działań przeciwko opozycji, stopniowalne pod względem restrykcji. Ważne było, aby uniknąć eskalacji napięcia, a w stosunku do Komitetu Obrony Robotników, ważnej organizacji opozycyjnej, stosować izolację, aby, jak powiedział 30 listopada 1976 r. gen. Adam Krzysztoporski, w czasie posiedzenia na temat sposobów zwalczania opozycji, „ta »choroba« nie roznosiła się po całym kraju" [Friszke 2008: 64]. Starano się odgrodzić KOR od hierarchów i duchowieństwa [Raina 1995: $276 \mathrm{i} \mathrm{n}$.], środowisk robotniczych oraz naukowych. W stosunku do KSS KOR aresztowania pojawiły się w sierpniu 1980 r. i miały związek z zaangażowaniem członków w akcję strajkową. Niemniej jednak wskutek interwencji Międzyzakładowego Komitetu Strajkowego w Gdańsku zostali oni zwolnieni. 
Różnego rodzaju sankcje spotkały członków Konfederacji Polski Niepodległej, pierwszej antykomunistycznej partii politycznej utworzonej w PRL. Wobec KPN stosowano grzywny, zastraszenia, profilaktyczne rozmowy z funkcjonariuszami milicji, aresztowania i procesy. Stanowisko władz PRL w stosunku do Konfederacji było bardzo radykalne. We wrześniu 1980 r. aresztowano Leszka Moczulskiego, a w kolejnych tygodniach innych konfederatów. Konfederatom postawiono zarzut zamiaru obalenia przemocą ustroju PRL i skazano ich na więzienie ${ }^{6}$.

W latach 70. XX w. znajdowali się w resorcie funkcjonariusze, którzy byli przeciwni polityce siłowej, jako mało skutecznej. W owym czasie los represjonowanych zależał od aktualnych potrzeb politycznych rządzących. O braku realnego zagrożenia ze strony opozycji świadczyła dwukrotna amnestia (w latach 1974 i 1977). W wyniku pierwszej amnestii z więzienia wyszli członkowie „Ruchu”, a w wyniku drugiej pozostający jeszcze w więzieniach korowcy. Niewielka liczebność wszystkich organizacji opozycyjnych pozwalała na skuteczną kontrolę.

Nie ma prostej odpowiedzi na pytanie, skąd brało się stosunkowo liberalne podejście do grup antykomunistycznych w latach 70. i 80. XX w. lub dlaczego w różnych momentach, po długim okresie względnego spokoju, dokonywano aresztowań (np. dlaczego uderzono w 1977 r. i szybko wycofano się z uderzenia; dlaczego zastosowano represje wiosną 1985 r., a nie w innym czasie). Wydaje się, że cyklicznie zaostrzone represje nie musiały mieć racjonalnego, bo uwzględniającego konkretne zagrożenie, wytłumaczenia. Nasilenie represji należy wiązać z dwiema kwestiami: 1) z taktyką uwzględniającą konieczność cyklicznego większego uderzenia, aby „ogłuszyć najbardziej rozzuchwalone ośrodki" (o takiej motywacji czytamy w liście Jakuba Bermana do Bolesława Bieruta z 7 października 1952 r. [Garlicki 1993: 196]; 2) z potrzebą liczenia się ze stanowiskiem resortu bezpieczeństwa, zadbania o morale funkcjonariuszy. Dokumenty Biura Politycznego KC PZPR pozwalają na konstatację, iż z punktu widzenia zadań aparatu, który miał skutecznie ścigać wrogów, wykonanie pracy operacyjnej niezakończone aresztowaniem obniżało „zapał” funkcjonariuszy i było demoralizujące. Protokoły posiedzeń Biura Politycznego zawierają odniesienia do morale funkcjonariuszy?

W latach 80. chodziło o osłabienie podziemia, ale nie przez represje fizyczne, lecz pogłębianie konfliktów w łonie opozycji, infiltrację, działalność w celu ograniczenia poparcia społeczeństwa dla opozycji [Kamiński 2003: 28; Dudek: 2003:

${ }^{6}$ Zob. Informacja o śledztwie przeciwko członkom kierownictwa antysocjalistycznego ugrupowania pn. Konfederacja Polski Niepodległej, [Warszawa 1981], [Kamiński, Piotrowski 2002: 323-324]; Konfederacja przed sadami PRL, Warszawa 1995, s. 4-6.

7 O negatywnym wpływie na kondycję aparatu bezpieczeństwa decyzji o zwolnieniu, zwłaszcza bezwarunkowych członków KPN, sygnalizował w 1980 r. A. Krzysztoporski (Protokót z posiedzenia Biura Politycznego KC PZPR 26 listopada 1980 r., [Włodek 1992: 183]. Z tego samego powodu Kiszczak domagał się 13 grudnia 1983 r. zgody towarzyszy na stanowcze działania wobec księdza Jerzego Popiełuszki, bo „należy uwzględnić kondycję psychiczną pracowników MSW. Jeśli dziś sprawę Popiełuszki potraktujemy lekko, to z kondycją tego aparatu będzie źle" [cyt. za: Rakowski 2004: 635-636]. 
101]. Przyjęta taktyka nie wykluczała jednostkowych pobić, morderstw ${ }^{8}$, aresztowań. Zwalczaniu podlegała np. Solidarność Walcząca. Od połowy grudnia 1983 r. do połowy 1984 r. aresztowano ponad 40 osób, które w areszcie pozostawały do amnestii z 21 lipca 1984 r. Drugi raz represji dokonano jesienią 1987 r.

Zatrzymania dotknęły współpracowników RWE. Aresztowano, osądzono i osadzono w więzieniu Józefa Szaniawskiego. W 1983 r. Zdzisław Najder został oskarżony o szpiegostwo i skazany na karę śmierci [Machcewicz 2007: 400].

Powyższej taktyki zakładającej cykliczne, ale jednocześnie ograniczone represje w żadnym razie nie można odnieść do strajkujących robotników oraz Niezależnego Samorządnego Związku Zawodowego „Solidarność”. Strajki były groźne ze względu na masowość, niesterowalność i brak kontroli. Trzy bunty społeczne, które wystąpiły w latach 1956, 1970 i 1980, pokazały determinację rządzących. Pacyfikacja działań uznanych za kontrrewolucję wymagała szczególnych sił i środków. Rządzący użyli mocy całego państwa w celu likwidacji zagrożenia i obrony istniejącego systemu władzy. Do pacyfikacji powstania poznańskiego użyto ponad 10 tys. żołnierzy oraz ciężkiego sprzętu bojowego - czołgów i dział pancernych [Nalepa 1992: 54]. Demonstracje w Poznaniu w 1956 r. zakończył „czarny czwartek”. W związku z Poznańskim Czerwcem zginęło 57 osób, rannych zostało 384 [Jarząb 2006: 107, 114]. Aresztowano prawie 750 osób, z czego 323 objęto aresztem, pozostałych zwolniono. Aresztowanym postawiono zarzuty [Makowski 2006: 222]. Wyroki nie były wysokie, co można było zawdzięczać aktywności części środowiska sędziowskiego w celu wprowadzenia praworządności [Sandorski 2007: 233 i n.].

W 1970 r. przeciwko strajkującym i demonstrującym mieszkańcom Wybrzeża zmobilizowano 61 tys. żołnierzy i zdecydowanie więcej sprzętu bojowego, czołgów i transporterów opancerzonych. Śmierć poniosło 45 osób, w tym 2 milicjantów, 1 żołnierz, rannych zostało 1164 osoby. Zatrzymano prewencyjnie i w czasie zajść 6634 osoby. Dokonana dla Biura Politycznego KC PZPR analiza struktury zatrudnienia i wieku pozwoliła stwierdzić, że zatrzymano przede wszystkim młodych robotników $^{10}$. W celu likwidacji kontrrewolucji władze użyły broni palnej. W $1970 \mathrm{r}$. siły porządkowe strzelały do bezbronnych ludzi, a następnie biły ich. Pojawiły się „drogi ognia”, tak jak wcześniej w Poznaniu i sześć lat później „ś́cieżki zdrowia” w Radomiu i Ursusie [Eisler 2000: 209, 224-225].

W 1976 r. represje wobec uczestników strajków objęły aresztowania i zwolnienia z pracy. Akcja milicji w Radomiu i Ursusie przyniosła łapanki i wyjątkowo brutalne

${ }^{8}$ W maju 1977 r. zginął Stanisław Pyjas. W latach 80. XX w. spośród znanych i mających oddźwięk społeczny przypadków brutalnego zachowania policji najgłośniejsze były: zatrzymanie i pobicie Grzegorza Przemyka, syna Barbary Sadowskiej, znanej opozycjonistki; uprowadzenie i zamordowanie ks. Jerzego Popiełuszki, śmierć ks. Niedzielaka w przededniu Okrągłego Stołu.

${ }^{9}$ Aleksander Ziemkowski uważał, że w czerwcu zginęło co najmniej 73 osoby, liczba ofiar śmiertelnych powstania poznańskiego mogła przekroczyć 100 osób [Ziemkowski 1990: 122].

${ }_{10}$ Zob. Kalendarium wydarzeń na Wybrzeżu opracowane w końcu stycznia 1971 r. dla Biura Politycznego [Domański 1991: 72, 82, 85]. 
bicie ludzi na ulicach i w komisariatach, wspomniane „ścieżki zdrowia”, czyli bicie pałkami przechodzących między szpalerem milicjantów złapanych uczestników zajść. Rozprawa była wyjątkowo brutalna (aresztowano 2,5 tysiąca osób). Częścią „wydarzeń” czerwcowych było maltretowanie i upokarzanie aresztowanych, zwolnienia $\mathrm{z}$ pracy tysięcy ludzi ${ }^{11} \mathrm{i}$ tzw. wilcze bilety (zakaz przyjmowania do pracy), dwa zgony. Kolegia do spraw wykroczeń oraz sądy wykorzystano do udowodnienia propagandowej tezy o chuligańskim charakterze wystąpień. Niektóre wyroki były bardzo wysokie (do 10 lat więzienia). Władze złamały konstytucyjne prawo do pracy, gdyż urzędy pracy nie przyjmowały podań osób wyrzuconych, starających się o ponowne zatrudnienie. Robotników nie broniły instytucje powołane do tego - związki zawodowe i sądy [Kawalec 1979: $9 \mathrm{i}$.]. Dopiero po jakimś czasie pozbawieni pracy ponownie ją uzyskali.

W 1981 r. z powodu niemożności przejęcia kontroli nad związkiem oraz uznania Solidarności za siłę kontrrewolucyjną zdecydowano o wprowadzeniu stanu wojennego. Przygotowania do siłowego rozwiązania problemu były realizowane od lata $1980 \mathrm{r}$. We wprowadzenie stanu wojennego zaangażowano ogromne siły i środki: bezpośrednio zaktywizowano setki tysięcy ludzi - 53 tys. żołnierzy, dużą część liczącego 200 tys. resortu spraw wewnętrznych, oddziały ZOMO, 46 tys. rezerwistów, część ze 150-tysięcznej liczby członków Ochotniczej Rezerwy Milicji Obywatelskiej, kilkadziesiąt tysięcy ochotników (tzw. grup samoobrony), 22 tys. funkcjonariuszy SB. Użyto także sprzętu na niespotykaną dotąd skalę: 1750 czołgów, 1900 wozów bojowych, 9000 samochodów, kilka eskadr helikopterów i samochody transportowe [Paczkowski 2007: 93-97; 1999: 363]. Bezpośrednim następstwem wprowadzenia 13 grudnia $1981 \mathrm{r}$. stanu wojennego była pacyfikacja strajków i demonstracji. 16 grudnia 1981 r. w kopalni „Wujek” w Katowicach śmierć poniosło 9 górników. Do 22 lipca 1983 r. życie w wyniku tego typu działań sił milicyjnych straciło co najmniej 30 osób, 20 innych zginęło w inny sposób, mający jednak związek z zastosowaniem siły przez oddziały milicji i Zmotoryzowane Oddziały Milicji Obywatelskiej. Przemoc wobec ludzi w postaci pozbawienia wolności objęła dwie grupy ludzi. Pierwszą internowaną grupą byli aktywni opozycjoniści. Internowano ponad 5 tysięcy aktywnych działaczy Solidarności. Nakaz internowania wydano 10132 razy, co oznaczało, że niektóre osoby były internowane kilkakrotnie. Między 13 grudnia 1981 r. a 21 lipca 1983 r. skazano 7,4 tys. osób.

Nastąpiły zwolnienia z pracy. W wyniku weryfikacji pracę straciło ponad tysiąc dziennikarzy. Większość internowanych było represjonowanych w pierwszych miesiącach obowiązywania stanu wojennego. Część z nich po złożeniu zobowiązania, że powstrzyma się od działalności politycznej, mogła odzyskać wolność. „Lojalki” były jednym z działań, które służyły „,przetrąceniu kręgosłupa”, de facto skutecznie eliminowały z życia politycznego. Dalsze zwolnienia nastąpiły w wyniku amnestii z 21 lipca 1983 r., kary więzienia uniknęło wówczas 500 osób, 1,1 tys. uniknęło kary

${ }^{11}$ W ocenie J.J. Lipskiego mogły wynosić od kilku do kilkunastu tysięcy ludzi [Lipski 1983: 32 i n.]. 
za wykroczenia; ok. 100 osobom złagodzono kary, a umorzono postępowania wobec 800. Według oficjalnych danych w więzieniach pozostały 83 osoby, w tym 11 z Komisji Krajowej NSZZ „Solidarność” i KOR [Paczkowski 2007: 103, 287-289].

W okresie stanu wojennego na karę śmierci zaocznie skazano 6 osób. Byli to: Zdzisław Najder, szef Rozgłośni Polskiej Radio Wolna Europa, Zdzisław Rurarz i Romuald Spasowski, dyplomaci, którzy poprosili o azyl polityczny na Zachodzie, Waldemar Mazurkiewicz, oficer SB, Jerzy Sumiński, oficer kontrwywiadu, Henryk Bogulak, pracownik MSW, oskarżeni o współpracę z obcym wywiadem [Majchrzak 2002: 64].

Charakterystyczna dla drugiej połowy lat 80 . XX w. strategia na rzecz wkomponowania części opozycji politycznej w system skutkowała liberalizacją i ograniczeniem represji. Efektem nowej strategii była amnestia: 11 września 1986 r. więzienia opuściło przeszło 200 więźniów politycznych (było 225). W założeniach amnestia miała przynieść korzyści przede wszystkim rządzącym, gdyż dawała możliwość poprawy wizerunku władzy tak na arenie wewnętrznej, jak i zewnętrznej. Rezygnacja z więzienia jako instrumentu walki politycznej była korzystna dla władz, gdyż bezpośrednio osłabiała opozycję, której głównym hasłem było domaganie się wolności dla uwięzionych. Nie znaczy to, że zrezygnowano z tego środka: represje były, ale łagodniejsze [Dominiczak 1997: 380 i n].

\section{ZAKOŃCZENIE}

Rekapitulując, należy zauważyć, że przemoc fizyczna (ale także materialna i emocjonalna) była warunkiem budowy komunizmu. Terror fizyczny został zastosowany wobec osób uznanych za wrogów systemu przede wszystkim w pierwszych latach istnienia Polski Ludowej. Życie straciło ponad 50 tys. ludzi, a cztery razy tyle znalazło się $\mathrm{w}$ więzieniach. Celem była eliminacja wszystkich środowisk, które mogłyby zagrozić nowej elicie władzy. Skutki terroru odczuli komunistyczni wrogowie w postaci podziemia niepodległościowego, jego zaplecza społecznego, a następnie grupy społeczne i zawodowe, które niejako ,nie mieściły się” w ramach nowego systemu - ziemianie, chłopi, kupcy i przedsiębiorcy, duchowni. Te ostatnie zetknęły się także z różnego rodzaju sankcjami materialnymi. Represje wobec Niemców i Ukraińców miały służyć unifikacji państwa i stabilizacji granic. Wrogowie w postaci części elity władzy byli wygodnymi kozłami ofiarnymi, które pomagały wyeliminować wątpliwości i niejako „uszczelnić” system.

Szczególnie bolesny był atak na tych wszystkich ludzi, którzy mieli za sobą przeszłość związaną z działalnością $\mathrm{w}$ niepodległościowym podziemiu. Jak trafnie zaznaczył Andrzej Friszke, dla „dużej części społeczeństwa udział w okupacyjnym podziemiu był najważniejszym doświadczeniem pokoleniowym, dla wielu kartą ich życia" [Friszke 2001: 149]. Uczestnicy ruchu oporu, traktowani jak wrogowie potencjalni, nawet jeżeli nie byli prześladowani, to zostali zmuszeni do przemilczenia swojej przeszłości. 
Cykliczne stosowanie przymusu fizycznego po 1956 r. miało głównie znaczenie „wychowawcze”, zależało od aktualnych potrzeb rządzących. Mobilizacja sił i środków w obliczu realnego zagrożenia, jakim były strajki robotnicze, służyła likwidacji ,kontrrewolucji”.

\section{BIBLIOGRAFIA}

Bierut, B. 1951. Przemówienie na zakończenie VI Plenum KC PZPR, „Nowe Drogi”, nr 1.

Chmielarz, A. 1998. Działania 64 dywizji Wojsk Wewnętrznych NKWD przeciwko polskiemu podziemiu, [w:] Wojna domowa czy nowa okupacja? Polska po roku 1944, A. Ajnenkiel (red.), Wrocław.

Domański, P. (oprac.). 1991. Tajne dokumenty Biura Politycznego. Grudzień 1970, Londyn.

Dominiczak, H. 1997. Organy bezpieczeństwa PRL 1944-1990. Rozwój i działalność w świetle dokumentów $M S W$, Warszawa.

Dubiański, W. 2004. Obóz pracy w Mystowicach w latach 1945-1946, Katowice.

Dudek, A. 2003. Limitowana liberalizacja. Opozycja w planach aparatu władzy PRL w potowie lat 80., „Arcana”, nr 2.

Dudek, A., Paczkowski, A. (oprac.). 2000. Aparat bezpieczeństwa w Polsce w latach 1950-1952. Taktyka, strategia, metody, Warszawa.

Eisler, J. 2000. Grudzień 1970: geneza, przebieg, konsekwencje, Warszawa.

Friszke, A. (oprac.) 2008. Rozmowy na Zawracie. Taktyka walki z opozycja demokratyczną: październik 1976 - grudzień 1979, A. Friszke, M. Zaremba (wybór), Warszawa 2008.

Friszke, A. 2001. Przystosowanie i opór. Rozważania nad postawami spolecznymi 1956-1970, [w:] Komunizm. Ideologia, system, ludzie, T. Szarota (red.), Warszawa.

Garlicki, A. 1993. Stalinizm, Warszawa.

Garlicki, A. 1993. Z tajnych archiwów, Warszawa.

Gierek, E. 2002. Sprawy przeciwdziałania antysocjalistycznym elementom [fragment przemówienia], [w:] Opozycja demokratyczna w Polsce w świetle akt KC PZPR (1976-1980), Ł. Kamiński, P. Piotrowski (wybór, wstęp i oprac.), Wrocław.

Gontarczyk, P. 2003. Polska Partia Robotnicza. Droga do władzy 1941-1944, Warszawa.

Gryciuk, F. 2003. Kolektywizacja wsi polskiej, [w:] Represje wobec wsi i ruchu ludowego (1944-1956). Materiaty z konferencji naukowej 5-6 grudnia 2002 r. w Rzeszowie, t. 1, J. Gmitruk, Z. Nawrocki (red.), Warszawa 2003.

Jarosz, D., Wolsza, T. 1993. Komisja Specjalna do Walki z Nadużyciami i Szkodnictwem Gospodarczym (1945-1956), „Pamięć i Sprawiedliwość. Biuletyn GKBZpNP IPN”, nr 36.

Jarząb, Ł. 2006. Udokumentowana liczba ofiar śmiertelnych i rannych poznańskiego czerwca 1956 r., „Kwartalnik Historyczny”, nr 4.

Kamiński, Ł. 2003. Władza wobec opozycji (1976-1989), „Pamięć i Sprawiedliwość”, nr 2.

Kamiński, Ł., Piotrowski, P. (oprac.) 2002. Opozycja demokratyczna w Polsce $w$ świetle akt KC PZPR (1976-1980), Wrocław.

Kawalec, S. 1979. Demokratyczna opozycja w Polsce. Wydarzenia czerwcowe i rok działalności Komitetu Obrony Robotników, Warszawa.

Konfederacja przed sadami PRL, Warszawa 1995.

Krupa, A. 2006. Aparat bezpieczeństwa $i$ wymiar sprawiedliwości wobec kolektywizacji wsi polskiej 1948-1956, Warszawa.

Lipski, J.J. 1983. KOR, Londyn.

Machcewicz, P. 2007. „Monachijska menażeria”. Walka z radiem Wolna Europa 1950-1989, Warszawa.

Madej, K., Żaryn, J., Żurek, J. (red.). 2003. Księga świadectw. Skazani na karę śmierci w czasach stalinowskich $i$ ich losy, Warszawa. 
Majchrzak, G. 2002. Wyroki śmierci w stanie wojennym, „Biuletyn Instytutu Pamięci Narodowej”, nr 11. Majchrzak, G., Paczkowski, A. (wybór i oprac.). 2004. Aparat bezpieczeństwa w Polsce wlatach 1953-1954. Taktyka, strategia, metody, wstęp A. Paczkowski, Warszawa.

Majer, P. 2000. Aparat bezpieczeństwa publicznego a organa wymiaru sprawiedliwości-elementy wspótpracy, [w:] Przestępstwa sędziów i prokuratorów w Polsce lat 1944-1956, W. Kulesza, A. Rzepiński (red.), Warszawa.

Makowski, E. 2006. Poznański Czerwiec 1956. Pierwszy bunt społeczeństwa w PRL, Poznań.

Minc, H. 1951. Przyczyny obecnych trudności w zaopatrzeniu i środki walki z tymi trudnościami, „Nowe Drogi", nr 4.

Morin, E. 1990. O naturze Związu Radzieckiego, Warszawa.

Nalepa, E.J. 1992. Pacyfikacja zbuntowanego miasta. Wojsko Polskie w Czerwcu 1956 r. w Poznaniu $w$ świetle dokumentów wojskowych, Warszawa.

Olejnik, L. 2003. Polityka narodowościowa Polski w latach 1944-1960, Łódź.

Paczkowski, A. 1994. Czy PRL była państwem polskim?, „Mówią Wieki”, nr 10/11.

Paczkowski, A. 1995. Pól wieku dziejów Polski 1939-1989, Warszawa.

Paczkowski, A. 1999. System represji w Polsce 1944-1989, [w:] S. Cortois, N. Werth i in., Czarna księga komunizmu. Zbrodnie, terror, prześladowania, wstęp do polskiego wydania K. Kersten, Warszawa.

Paczkowski, A. 2007. Wojna polsko-jaruzelska. Stan wojenny w Polsce 13 XII-22 VII 1983, wyd. zmienione i poprawione, Warszawa.

Pawlikowski, L. 2004. Tajny front zimnej wojny. Uciekinierzy z polskich służb specjalnych 1956-1964, Warszawa.

Poksiński, J. 1992. „TUN” Tatar-Utnik-Nowicki. Represje wobec oficerów Wojska Polskiego w latach 1949-1956, Warszawa.

Protokól z posiedzenia Zespolu KC ds. Polityki Wyznaniowej w dniu 19 listopada 1971 r., [w:] Tajne dokumenty Państwo-Kościót 1960-1980, Londyn 1996.

Raina, P. 1995. Rozmowy z władzami PRL. Arcybiskup Dąbrowski w stużbie Kościoła i narodu, t. 1, Warszawa.

Rakowski, M.F. 2004. Dzienniki polityczne 1981-1983, Warszawa.

Rolicki, J. 1990. Edward Gierek: Przerwana dekada, Warszawa.

Rzepińska, I. 1997. Konfiskata mienia. Studium z historii polityki kryminalnej, Warszawa.

Sandorski, J. 2007. Wymiar sprawiedliwości PRL w 1956 r. na tle procesów uczestników „Poznańskiego Czerwca”, [w:] Poznański Czerwiec 1956. Uwarunkowania-Przebieg-Konsekwencje. Materiały z międzynarodowej konferencji naukowej, [Poznań 22-23 czerwca 2006], K. Białecki, S. Jankowiak (red.), Poznań.

Słabek, H. 1995. Narodowa kondycja Polaków (1945-1989), „Dzieje Najnowsze”, nr 4.

Słabek, H. 1996. Intelektualiści i Wielki Strach (na przełomie lat czterdziestych i pięćdziesiątych), „Dzieje Najnowsze", nr 1.

Spałek, R. 2007. Potega szpiegomanii. Departament X w poszukiwaniu ,wroga wewnętrznego” w kierownictwie komunistycznym w Polsce (1948-1956), [w:] Departament X MBP. Wzorce-struktury-działanie, K. Rokicki (red.), Warszawa.

Stola, D. 2000. Kampania antysyjonistyczna w Polsce 1967-1968, Warszawa.

Torańska, T. 1989. Oni, Warszawa.

Trembicka, K. 2013. Wrogowie w myśli politycznej Polskiej Zjednoczonej Partii Robotniczej, Lublin.

Ważniewski, W. 1991. Walka polityczna w kierownictwie PPR i PZPR 1944-1964, Toruń.

Werblan, A. 1991. Stalinizm w Polsce, Warszawa.

Włodek, Z. (oprac.). 1992. Tajne dokumenty Biura Politycznego. PZPR a „,Solidarnośc’” 1980-1981, Londyn.

Wolsza, T. 2001. Codzienność w peerelowskim więzieniu w latach 1945-1956, „Polska 1944/1945- 1989. Studia i Materiały” 2001, t. 5: Życie codzienne w Polsce 1945-1955, Warszawa.

Woźniczka, Z. 1996. Środowiska postsanacyjne w Polsce po 1945 (zarys problemu), „,Dzieje Najnowsze”, nr 2. 
Woźniczka, Z. 2007. Centralny obóz pracy w Jaworznie na tle stalinowskiego systemu represji (1945-1950), [w:] Obóz dwóch totalitaryzmów Jaworzno 1943-1956. Materiały konferencji naukowej „Historia martyrologii i obozów odosobnienia w Jaworznie w latach 1939-1956”, wyd. drugie uzupełnione i popr., K. Mieroszewski, Z. Woźniczka (red.), Jaworzno.

Ziemkowski, A. 1990. Ofiary i straty ludzkie, [w:] Poznański Czerwiec 1956, J. Maciejewski, Z. Trojanowicz (red.), Poznań.

Żaryn, J. 2005. Kościół katolicki w PRL-zagadnienia, hipotezy, prowokacje, „Pamięć i Sprawiedliwość”, nr 1 .

\section{ABSTRACT}

The subject of the article is the physical violence as a way to implement the communist political thought in the People's Poland in the years 1944-1989. The study involved the category of the enemy. In a totalitarian political system, there was a feedback loop between the revolutionary reality and the enemy. On the one hand, the revolutionary reality could not do without the enemy who was constant, only its image was changing. On the other hand, the existence of the enemy sanctioned the use of extraordinary measures. An inevitable part of the revolution was violence. It was the way to achieve the goal at the stage of the struggle for power and its maintenance. In the People's Poland, ways to combat with the enemy were flexible, depending on the purpose and needs: from direct physical repression to the relatively mild harassment. The scale of repression was a derivative of the natural evolution of the political system of the People's Poland.

Key words: enemy, the People's Poland, the Polish United Workers' Party, physical violence

\section{BIOGRAM}

Krystyna Trembicka, prof. dr hab., zatrudniona w Zakładzie Teorii Polityki i Metodologii Politologii Wydziału Politologii UMCS w Lublinie; specjalistka w zakresie myśli politycznej, historii najnowszej, systemów politycznych (totalitaryzm), partii i ruchów politycznych (ruch komunistyczny, KPP, PZPR, opozycja antykomunistyczna w Polsce), historii stosunków międzynarodowych (systemy bezpieczeństwa). Kontakt e-mail: krystynatrembicka@wp.pl 